$$
\text { データ同化との融合によるフェーズフィールド法の進展 }
$$

\title{
Progress in phase-field method integrated with data assimilation
}

\author{
山中 晃徳 \\ Akinori YAMANAKA
}

\section{1. はじめに}

アルミニウム合金やマグネシウム合金などの軽金属材料 は, 社会の省エネルギー化を実現するために必要不可欠な材 料である。一方で, 日本では少子高齢化が進み労働人口が減 少するなか, 従来よりも効率的に金属材料および金属製品を 設計・開発・製造することが求められている。本連載講座の テーマである計算材料学や計算固体力学に基づく数值シミュ レーションは, 材料の研究開発を効率化するために今後ます ます必要となる技術である。

本連載講座でも解説するように, 金属材料の組織形成過程 や変形挙動の数值シミュレーション方法として, 電子・原 子・分子のスケールでは第一原理計算や分子動力学計算が使 用されている。ミクロスケールでは, モンテカルロ法やセル オートマトン法に加えて, フェーズフィールド法が盛んに研 究されている。また, メゾスケールからマクロスケールでは 結晶塑性理論や弾塑性理論に基づく有限要素法が広く使用さ れている。このような計算材料学や計算固体力学に基づく数 值シミュレーションの研究は, 最近になってさらに注目を集 めている。その理由は, 2000 年初頭に米国において揭げら れた ICME構想, その後の 2011 年にマテリアルズ・ゲノム・ イニシアティブ (Materials Genome Initiative : MGI) と名づけ られた材料研究のガイドラインが策定されたことであると思 われる ${ }^{1)}$ 。MGI は, 材料開発の短期化・低コスト化のために 必要な実験・計算技術の発展に加えて, 米国ならびに世界中 にある材料デー夕を基礎にデー夕科学を活用して, 従来の材 料開発期間を大幅に短縮することを目指している。この MGI の策定を契機に，最近では計算材料学に加えてデー夕科学を 活用した数值シミュレーションによる材料開発のための基礎 研究が世界的に活発である。

本講座では, 著者がこれまで研究を進めてきたフェーズ フィールド法 ${ }^{2)} に よ る$ 材料組織形成の数值シミュレーショ ンに, データ科学的手法を適用した事例を紹介する。「デー 夕科学」と言っても, 非常に多くの理論や計算アルゴリズム がある。本稿において，そのすべてを解説することはできな いが，著者は強力なデー夕科学的手法のひとつであるデータ 同化 ${ }^{3), 4)}$ に注目している。データ同化は, 実験と理論モデ
ル（シミュレーションモデル）を統合する方法論であり, 実 験結果に基づきシミュレーション結果（対象とする物理現象 の予測結果）の精度向上のみならず，モデルに含まれるパラ メータの逆推定やシミュレーションに適用する初期条件, 境 界条件の最適化を行うことができる ${ }^{4)}$ 。本解説では, デー夕 同化とフェーズフィールド法の融合により, 従来のフェーズ フィールド法に基づく材料組織形成シミュレーションに比ベ て，何ができるようになるのかを紹介する。

本講座の構成は以下の通りである。はじめに, デー夕同化 の基礎となる考え方を説明する。特に, シミュレーションに 確率論を導入し, ベイズの定理を利用して, シミュレーショ ンに実験を統合する意味を説明する。次に, 著者が使用する データ同化アルゴリズムであるアンサンブルカルマンフィル 夕 $^{5)}$ とその基礎となるカルマンフィルタ ${ }^{6)}$ を説明し, デー 夕同化がどのように機能しているのかを説明する。そして, アンサンブルカルマンフィルタをマルチフェーズフィールド 法による静的再結晶シミュレーションに適用した事例を紹介 する ${ }^{7)}$ 。なお, デー夕同化は, 確率論や統計学の知識を必要 とするため, 著者も含め初学者には難しく感じる。そこで本 解説では, 機械工学や材料工学に関係する読者を想定して, できるだけ平易に説明することを試みた。そのため, データ 同化の真の理解に必要な数学的背景や定式の詳細は不十分で あることは否めない。フェーズフィールド法の理論について も簡単に触れるのみとした。読者にとって不足する内容につ いては, 過去の優れた文献を参照頂きたい。データ同化に関

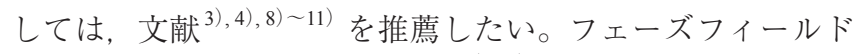
法については, いくつかの著書 ${ }^{12)}$,13) や本連載講座を含む解 説論文 ${ }^{14) ~ 16) ~}$ がすでに出版されているので, 参照して頂き たい。また, フェーズフィールド法へのデータ同化の適用に ついても, 最近出版された論文にいくつかの報告 ${ }^{19)}$ 21) が ある。

\section{2. データ同化の基礎}

データ同化の各種手法は, 非逐次データ同化と逐次データ

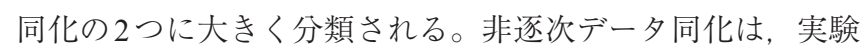
データ（データ同化の分野では, 観測データと呼ばれること も多い)の全体を捉えて, その実験データを最もよく再現

東京農工大学大学院工学研究院先端機械システム工学部門（†184-8588 東京都小金井市中町 2-24-16） Division of Advanced Mechanical Systems Engineering, Institute of Engineering, Tokyo University of Agriculture and Technology (2-24-16 Naka-cho, Koganei-shi, Tokyo 1848588) E-mail: a-yamana@cc.tuat.ac.jp

受付日：2019年3月31日＼cjkstart受理日：2019年5月20日 
$6 \quad||||||||||||||||||||||||||||||||||||||||||||||||||||||||||||||||||||||||||||||||||||||||||||||||||||||||||||||||||||||||||||||||||||||||||||||||||||||||||||||||||||||||||||||||||||||||||||||||||||||||||||||||||||||||||||||||||||||||||||||||||||||||||||||||||||||||||||||||||||||||||||||||$

するモデルの初期值やパラメータをすることができる。非 逐次データ同化の代表的なアルゴリズムとしては，3次元変 分 (3DVar) 法や4次元変分 (4DVar) 法がある。次に述べる 逐次デー夕同化に比べて，計算コストが小さいため，計算規 模が大きいシミュレーションにも適用することができる。そ の一方で，シミュレーションモデルへの適用（実装）には， 高度な数学的枠組みを利用するため, 初学者には困難を伴う ことが多い。材料工学への 4 次元変分法の適用とその有効性 については，文献17）に詳しく解説されている。

他方で，本解説で適用事例を紹介する逐次デー夕同化は， 時系列の実験デー夕を逐次的にシミュレーションモデルに統 合する。これにより，実験デー夕を再現するシミュレーショ ン結果を得るのみならず，初期条件・境界条件の最適化，さ らにはパラメータの逆推定を行うことができる。逐次データ 同化の代表的なアルゴリズムには, 線形なシミュレーション モデルに適用できるカルマンフィルタや非線形なシミュレー ションモデルに適用できるアンサンブルカルマンフィルタ, 粒子フィル夕などがある。逐次デー夕同化は，計算規模が大 きくなると非常に大きな計算コストが必要となる。しかしな がら, 非逐次デー夕同化に比べて, シミュレーションモデル への実装が容易という長所がある。この長所が，著者が注目 し，本解説において読者に紹介する理由である。

データ同化を適用したシミュレーションと従来のシミュ レーションの大きな違いの一つは，後者では一つの初期条件 に対して, シミュレーション結果は一意に決まる。すなわち, 決定論的なシミュレーションである。それに対して，データ 同化を適用したシミュレーションでは，シミュレーション結 果が一意に定まらず，幅を持った確率分布として与えられ る。この確率分布の幅は, シミュレーション結果の不確かさ を表す。シミュレーションモデルは, 対象とする自然現象の 本質を捉えたモデルであり，決してその現象を完全に再現す ることはない。すなわち, シミュレーションモデルには不完 全さがある。さらに, シミュレーション結果は, 初期条件・ 境界条件やパラメータにも依存し, これらに起因する不確か さも含んでいる。データ同化では，そうした不完全さや不確 かさを含めたシミュレーション結果を表す確率分布の時間変 化を追跡する。また，シミュレーション結果を確率分布で表 現することにより，実験データにシミュレーション結果を近 づけるということが可能となる。このとき, 逐次デー夕同化 は，シミュレーション結果を実験データにどれぐらい近づけ るべきかを提示してくれる。これを利用して，実験データが 得られるたびに，シミュレーション結果を修正する。結果的 に実験データを再現するシミュレーション結果を得て, 適切 な初期条件・境界条件およびパラメー夕を逆推定することが できる。次節では，デー夕同化に扔いて，実験デー夕に近づ くようにシミュレーション結果を修正する原理となるべイズ の定理を説明する。

\section{1 ベイズの定理}

ベイズの定理は，確率の乗法定理から導かれる。確率の乗

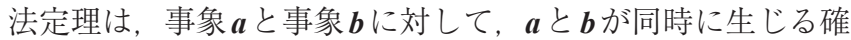
率，すなわち同時確率 $P(\boldsymbol{a}, \boldsymbol{b})$ が次式で与えられることを表 す。

$$
P(\boldsymbol{a}, \boldsymbol{b})=P(\boldsymbol{a} \mid \boldsymbol{b}) P(\boldsymbol{b})
$$

ここで, $P(\boldsymbol{a} \mid \boldsymbol{b})$ は事象 $\boldsymbol{b}$ が生じるもとで事象 $\boldsymbol{a}$ が生じる条件 つき確率を表す。確率の乗法定理は，事象 $\boldsymbol{a}$ と事象 $\boldsymbol{b}$ が入れ 替わっても成立するので，式（1）は次式のように書き換える ことができる。

$$
P(\boldsymbol{b}, \boldsymbol{a})=P(\boldsymbol{b} \mid \boldsymbol{a}) P(\boldsymbol{a})
$$

式(1)と式(2)より，次式に示すべイズの定理 ${ }^{22)}$ が導かれる。

$$
P(\boldsymbol{b} \mid \boldsymbol{a})=\frac{P(\boldsymbol{a} \mid \boldsymbol{b}) P(\boldsymbol{b})}{P(\boldsymbol{a})}
$$

ベイズの定理は, 確率たけではなく確率密度関数 (Probability Density Function: PDF) についても成立する。b をシミュレーションモデルで予測する状態変数を表す確率変 数 $\boldsymbol{x}$ とし, $\boldsymbol{a}$ をシミュレーションモデルで予測された状態に 対応する実験デー夕を表す確率変数 $\boldsymbol{y}$ とすると, 式(3) は次 式のように表される。

$$
p(\boldsymbol{x} \mid \boldsymbol{y})=\frac{p(\boldsymbol{y} \mid \boldsymbol{x}) p(\boldsymbol{x})}{p(\boldsymbol{y})}
$$

ここで, $p(\boldsymbol{x})$ はシミュレーションモデルにより予測された 状態のPDFであり, 実験データが得られる前に知り得た状態 に関する事前情報を表すPDFである。これを事前分布（Prior $\mathrm{PDF})$ と呼ぶ。 $p(\boldsymbol{y} \mid \boldsymbol{x})$ は, 実験データがシミュレーションモ デルで予測された状態とどれぐらい近しいかを表すPDFで あり, 尤度 (Likelihood) と呼ばれる。 $p(\boldsymbol{x} \mid \boldsymbol{y})$ は, 実験デー 夕が得られた後に，その実験デー夕を踏まえて予測された状 態を表すPDFであり，事後分布（Posterior PDF）と呼ばれる。 $p(\boldsymbol{y})$ は，実験データに関するPDFを表すが，実験データは すでに測定されているので定数と考えることができる。した がって，ベイズの定理は次式のように表すことができる。

$$
p(\boldsymbol{x} \mid \boldsymbol{y}) \propto p(\boldsymbol{y} \mid \boldsymbol{x}) p(\boldsymbol{x})
$$

逐次データ同化において, 式(5) の意味は次の通りであ る：シミュレーションモデルの不完全さや初期条件・境界条 件，パラメータの不確かさを含む，ある時刻でのシミュレー ション結果を表す確率密度関数（事前分布；Prior PDF）と 実験デー夕を表す確率密度関数（尤度；Likelihood）の掛け 算を計算することで，実験デー夕を反映するように修正され たシミュレーション結果を表す確率密度関数（事後分布； Posterior PDF）を得ることができる。得られた事後分布の平 均值を算出すれば，シミュレーションモデルで予測する状態 のうち最も確率として高い状態を知ることができる。事後分 布の分散（または共分散）を評価すれば，実験デー夕を反映 したうえでのシミュレーション結果の不確かさを評価するこ とができる。次節では，簡単な 1 次元のPDFを用いて，デー 夕同化においてべイズの定理がどのように機能するかを説明 する。

\section{2 確率密度関数}

PDFには，ベルヌイ分布やベー夕分布など様々な分布があ るが，デー夕同化ではガウス分布が多用される。確率変数 $\boldsymbol{x}$ 
が, 1 次元で表される場合, ガウス分布は次式で与えられる。

$$
p(\boldsymbol{x} \mid \mu, \sigma)=\frac{1}{\sigma \sqrt{2 \pi}} \exp \left[-\frac{(\boldsymbol{x}-\mu)^{2}}{2 \sigma^{2}}\right]
$$

ここで, $\sigma^{2}$ は式(6)で与えられるPDFの分散であり, $\sqrt{\sigma^{2}}=\sigma$ は標準偏差である。 $E(p(\boldsymbol{x} \mid \mu, \sigma))$ にあたる平均值である。以後, 確率変数 $\boldsymbol{x}$ が平 均值 $\mu$, 分散 $\sigma^{2}$ のガウス分布に従うとき, $\boldsymbol{x}=N\left(\mu, \sigma^{2}\right)$ と表記 する。

式（6）を用いて，ベイズの定理の意味を詳しく説明する ための例として, 材料の弾性変形で生じる応力 $S$ を予測す るシミュレーションモデルを考える。その応力予測モデル は, ある時刻 $t$ において, 応力の予測值を $10 \mathrm{MPa}$ と予測して いたとする。一方で，その予測值のばらつきが標準偏差と して $0.8 \mathrm{MPa}$ とする。したがって, 応力予測モデルの予測值 を, 平均值 $\mu_{\text {prior }}=10$, 分散 $\sigma_{\text {prior }}^{2}=0.64$ のガウス分布で与えるな らば, $S=N\left(\mu_{\text {prior }}, \sigma_{\text {prior }}^{2}\right)=N\left(10,0.8^{2}\right)$ と表される。式(5) のべ イズの定理において，これは事前分布 $p(\boldsymbol{x})$ に対応する。一 方で，同時刻において実験で測定された応力は $12 \mathrm{MPa}$ であ り，その測定誤差が標準偏差で $0.5 \mathrm{MPa}$ であったとする。こ の実験データもガウス分布で表されると仮定すれば，それは 式(5)の尤度に対応し, $p(\boldsymbol{y} \mid \boldsymbol{x})=N\left(\mu_{\mathrm{obs}}, \sigma_{\mathrm{obs}}^{2}\right)=N\left(12,0.5^{2}\right)$ の ように表される。このとき，べイズの定理によれば，事後分 布すなわち応力予測モデルの予測值の修正は, 次式で計算さ れる。

$$
p(\boldsymbol{x} \mid \boldsymbol{y}) \propto p(\boldsymbol{y} \mid \boldsymbol{x}) p(\boldsymbol{x})=N\left(\mu_{\text {prior }}, \sigma_{\text {prior }}^{2}\right) N\left(\mu_{\mathrm{obs}}, \sigma_{\mathrm{obs}}^{2}\right)
$$

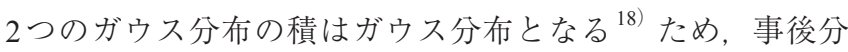
布は次式のように表される。

$$
p(\boldsymbol{x} \mid \boldsymbol{y}) \propto \frac{1}{\sigma_{\text {post }} \sqrt{2 \pi}} \exp \left[-\frac{\left(\boldsymbol{x}-\mu_{\text {post }}\right)^{2}}{2 \sigma_{\text {post }}^{2}}\right]
$$

ここで, 式(8) の事後分布の平均值 $\mu_{\text {post }}$ と標準偏差 $\sigma_{\text {post }}$ は, それぞれ次式で与えられる9)。

$$
\begin{gathered}
\mu_{\text {post }}=\frac{\sigma_{\text {prior }}^{2} \mu_{\text {obs }}+\sigma_{\text {obs }}^{2} \mu_{\text {prior }}}{\sigma_{\text {prior }}^{2}+\sigma_{\text {obs }}^{2}} \\
\sigma_{\text {post }}=\frac{\sigma_{\text {prior }}^{2} \sigma_{\text {obs }}^{2}}{\sigma_{\text {prior }}^{2}+\sigma_{\text {obs }}^{2}}
\end{gathered}
$$

図1に，事前分布と尤度，それらの積で表される事後分布 を図示する。事後分布は, 事前分布よりも標準偏差が小さい, すなわち不確かさが小さい尤度の方に近づくように，移動す ることがわかる。その移動量を算出するために, 式(9) で示 した事後分布の平均值を次式のように書き換える。

$$
\mu_{\text {post }}=\left(\frac{\sigma_{\text {prior }}^{2}}{\sigma_{\text {prior }}^{2}+\sigma_{\text {obs }}^{2}}\right) \mu_{\mathrm{obs}}+\left(\frac{\sigma_{\text {obs }}^{2}}{\sigma_{\text {prior }}^{2}+\sigma_{\text {obs }}^{2}}\right) \mu_{\text {prior }}
$$

ここで，式(11）右辺の括弧内を次式で定義する。

$$
K=\frac{\sigma_{\text {prior }}^{2}}{\sigma_{\text {prior }}^{2}+\sigma_{\text {obs }}^{2}}
$$

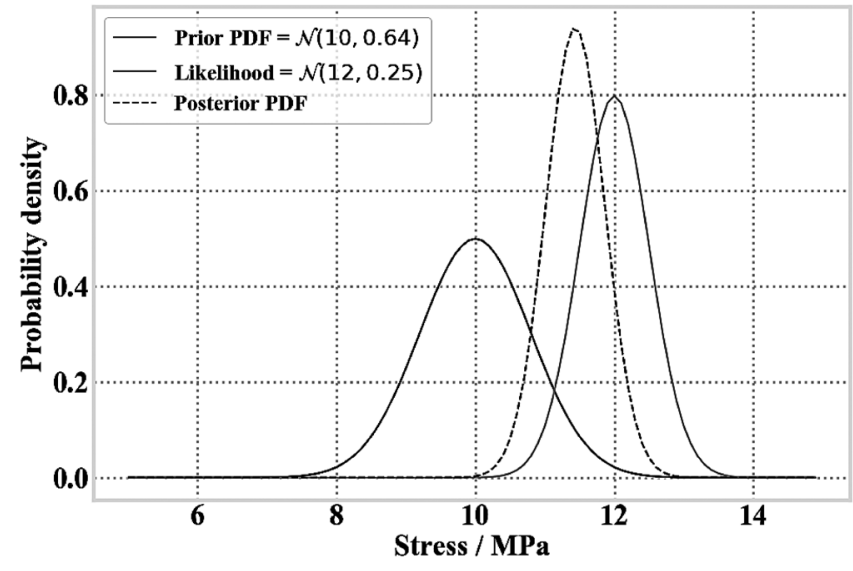

図1＼cjkstart事前分布と尤度およびベイズの定理で計算される 事後分布

式(12)を用いると, 式(11) は次式で表される。

$$
\mu_{\text {post }}=K \mu_{\text {obs }}+(1-K) \mu_{\text {prior }}=\mu_{\text {prior }}+K\left(\mu_{\text {obs }}-\mu_{\text {prior }}\right)
$$

式(13）の右辺第 1 式より, 事後分布の平均值は, 事前分布 の平均值と尤度の平均值の重み付け和であり, その重み係数 が式(12) のKであると考えることができる。また，式(13) の右辺第 2 式は, 事前分布の平均值（すなわちシミュレー ション結果）と実験データの差に $K$ を乗じた量が事前分布の 平均值の修正量となることを意味する。さらに, 事前分布の 分散 $\sigma_{\text {prior }}^{2}$ が非常に小さい, すなわち応力予測モデルの予測精 度が高いときには, $K$ は小さくなり, 事前分布（すなわち応 力予測モデルの計算結果）を信頼した事後分布が得られる。 逆に, 尤度の分散 $\sigma_{\mathrm{obs}}^{2}$ が小さい, すなわち実験データが信頼 できるときには, 応力予測モデルの計算結果がより実験デー 夕に近づくように事後分布が計算される。

一方，式(10) の事後分布の分散は，Kを用いて次式のよ うに表すことができる。

$$
\sigma_{\text {post }}=\frac{\sigma_{\text {prior }}^{2} \sigma_{\text {obs }}^{2}}{\sigma_{\text {prior }}^{2}+\sigma_{\text {obs }}^{2}}=K \sigma_{\text {obs }}^{2}=(1-K) \sigma_{\text {prior }}^{2}
$$

式(14）は，事後分布の分散，すなわち実験データを反映す るように修正された予測結果の不確かさは, 事前分布と尤度 の両方の分散に基づき計算されることを意味する。

以上で示したように, 本解説で紹介する逐次データ同化で は，実験データがない時間においては，シミュレーションモ デルを用いて「PDFの平均と分散の時間変化を予測」し，実 験デー夕がある時刻においては, ベイズの定理に基づきシ ミュレーション結果の「PDFの平均と分散の修正」を行うと 考えてよい。本節では, 確率変数である状態変数が 1 次元の スカラーの場合を例に説明したが, フェーズフィールド法な どの多くのシミュレーションモデルでは, 状態変数が多次元 である。次節以降では, 多次元の状態変数の場合に, データ 同化に拉いて，どのようにしてPDFの変化を追跡するのか をカルマンフィルタとアンサンブルカルマンフィルタを例に 具体的に説明する。 


\section{3 カルマンフィルタ}

カルマンフィルタ ${ }^{6)}$ は, 状態変数の時間変化が線形なシ ミュレーションモデルで計算できる場合，すなわち行列計算 で計算される場合に適用できる逐次デー夕同化のアルゴリズ ムである。

カルマンフィルタの詳細を説明するため, 状態変数が次式 に示す $n$ 次元べクトル $\boldsymbol{x}$ で表されることを考える。

$$
\boldsymbol{x}=\left(\begin{array}{llll}
x_{1} & x_{2} & \cdots & x_{n}
\end{array}\right)^{\mathrm{T}}
$$

データ同化においては, 式(15) は状態べクトルと呼ばれる。 状態べクトル $\boldsymbol{x}$ がガウス分布に従うとすると, そのPDFは, 式(8) と同様に次式のように表される。

$$
\begin{aligned}
p(\boldsymbol{x} \mid \boldsymbol{\mu}, \boldsymbol{\Sigma}) & =N(\boldsymbol{\mu}, \boldsymbol{\Sigma}) \\
& =\frac{1}{\sqrt{(2 \pi)^{n}|\boldsymbol{\Sigma}|}} \exp \left[-\frac{1}{2}(\boldsymbol{x}-\boldsymbol{\mu})^{\mathrm{T}} \boldsymbol{\Sigma}^{-1}(\boldsymbol{x}-\boldsymbol{\mu})\right]
\end{aligned}
$$

ここで， $\mu$ は次式に示す平均べクトルである。

$$
\boldsymbol{\mu}=\left(\begin{array}{llll}
\mu_{1} & \mu_{2} & \cdots & \mu_{n}
\end{array}\right)^{\mathrm{T}}
$$

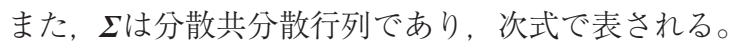

$$
\Sigma=\left[\begin{array}{cccc}
\sigma_{1}^{2} & \sigma_{12} & \cdots & \sigma_{1 n} \\
\sigma_{21} & \sigma_{2}^{2} & \cdots & \sigma_{2 n} \\
\vdots & \vdots & \ddots & \vdots \\
\sigma_{n 1} & \sigma_{n 2} & \cdots & \sigma_{n}^{2}
\end{array}\right]
$$

式(18)の対角成分は, 式(15)の状態ベクトルの各成分の分 散を表し, 非対角成分は共分散, すなわち各成分間の相関を 表す。

カルマンフィルタは, 時刻 $t-1$ での状態ベクトル $\boldsymbol{x}_{t-1}$ から 時刻 $t$ での状態べクトル $\boldsymbol{x}_{t}$ への遷移を表すシステムモデルが, 次式のような行列計算で表される場合にのみ適用できる。

$$
\boldsymbol{x}_{t}=\boldsymbol{F} \boldsymbol{x}_{t-1}+\boldsymbol{G}_{t} \boldsymbol{v}_{t}
$$

ここで, $\boldsymbol{F}$ は状態変数の時間変化を与える行列であり, 状態 遷移行列と呼ばれる。 $\boldsymbol{v}_{t}$ は, 白色ノイズを表し, 平均べクト ル 0 , 分散共分散行列 $\boldsymbol{Q}_{t}$ のガウス分布で与えられるとする。 $\boldsymbol{G}_{t}$ は駆動行列と呼ばれ, 状態べクトルの各要素にノイズを与 えるために用いられる。式(19) 右辺の $\boldsymbol{G}_{t} \boldsymbol{v}_{t}$ は, 式(19)で表 現される状態べクトルを確率変数としたとき, そのPDFが ガウス分布に従うように，加えられたものと考えることがで きる。

一方, 状態変数と実験デー夕を結びつける観測モデルを次 式で定義する。

$$
\boldsymbol{y}_{t}=\boldsymbol{H} \boldsymbol{x}_{t}+\boldsymbol{w}_{t}
$$

ここで， $y_{t}$ は観測ベクトルと呼ばれ，実験データそのもの を表すべクトルである。実験データは，シミュレーションで 計算する状態変数と同じ次元であるとは限らない。例えば, フェーズフィールド法による組織形成シミュレーションを例 にすると, 多くの場合, 空間分解能は実験データの方が低く, 観測ベクトルの次元は状態ベクトルよりも小さい。そのた め, 観測行列と呼ばれる行列 $\boldsymbol{H}$ を導入し, 状態べクトル $\boldsymbol{x}_{t}$ の
各成分のうち観測ベクトルの各成分と比較可能な成分を抽出 する。 $\boldsymbol{w}_{t}$ は, 観測データの不確かさや誤差を表すノイズであ $\eta$, 通常は平均ベクトル $\mathbf{0}$, 分散共分散 $\boldsymbol{R}_{t}$ のガウス分布で与 えられる。データ同化では， $\boldsymbol{R}_{t}$ を観測誤差共分散行列と呼ぶ。 2.2 節で述べたように, 逐次データ同化では, 実験デー夕 のない時間ではシミュレーションモデルを用いて「PDFの平 均と分散の時間変化を予測」する。多次元の状態変数を考 える場合には，「PDFの平均べクトルと分散共分散行列の時 間変化を予測」する。システムモデルに式(19)を用いると， $\mathrm{PDF}$ の平均ベクトルの時間変化は, 次式で予測される。

$$
\boldsymbol{x}_{t \mid t-1}=\boldsymbol{F} \boldsymbol{x}_{t-1 \mid t-1}
$$

ここで， $\boldsymbol{x}_{t \mid t-1}$ は，時刻 $t-1$ までの観測データを反映したうえ で予測した, 時刻 $t$ での平均ベクトルを示す。一方, 分散共 分散行列の予測は，次式で与えられる。

$$
\boldsymbol{P}_{t \mid t-1}=\boldsymbol{F P}_{t-1 \mid t-1} \boldsymbol{F}^{-1}+\boldsymbol{G}_{t} \boldsymbol{Q}_{t} \boldsymbol{G}_{t}^{-1}
$$

式(22)で与えられる分散共分散行列は, 式(14)における $\sigma_{\text {prior }}^{2}$ に相当し，予測誤差共分散行列と呼ばれる。

実験データが存在する時刻においては, ベイズの定理に基 づき事後分布の平均ベクトルと分散共分散行列を計算する。 カルマンフィルタでは, 事後分布の平均ベクトルは, 次式で 表される ${ }^{9)}$ 。

$$
\boldsymbol{x}_{t \mid t}=\boldsymbol{x}_{t \mid t-1}+\boldsymbol{K}_{t}\left(\boldsymbol{y}_{t}-\boldsymbol{H} \boldsymbol{x}_{t \mid t-1}\right)=\boldsymbol{K}_{t} \boldsymbol{y}_{t}+\left(\boldsymbol{I}-\boldsymbol{K}_{t}\right) \boldsymbol{x}_{t \mid t-1}
$$

式(23)の右辺と式(13)式の右辺を比較すると, 両者は同様 の意味を示すことがわかる。カルマンフィルタでは, 式 (23) の $\boldsymbol{K}_{t}$ をカルマンゲインと呼び, 次式で与えられる行列であ る。

$$
\boldsymbol{K}_{t}=\boldsymbol{P}_{t \mid t-1} \boldsymbol{H}^{\mathrm{T}} \boldsymbol{S}_{t}^{-1}
$$

ここで， $\boldsymbol{S}_{t}^{-1}$ は次式で表される。

$$
\boldsymbol{S}_{t}=\boldsymbol{H P}_{t \mid t-1} \boldsymbol{H}^{\mathrm{T}}+\boldsymbol{R}_{t}
$$

さらに，事後分布の共分散行列は，次式で計算される。

$$
\boldsymbol{P}_{t \mid t}=\left(\boldsymbol{I}-\boldsymbol{K}_{t} \boldsymbol{H}\right) \boldsymbol{P}_{t \mid t-1}
$$

式(26)において， $\boldsymbol{P}_{t \mid t-1}$ と $\boldsymbol{P}_{t \mid t}$ はそれぞれ式(14)における $\sigma_{\text {prior }}^{2}$ と $\sigma_{\text {posterior }}^{2}$ に対応することから, 式(26) と式(14)は同様の意 味を示すことがわかる。デー夕同化においては, 式(26)で 表される分散共分散行列を解析誤差共分散行列と呼ぶ。

\section{4 アンサンブルカルマンフィルタ}

カルマンフィルタは，状態ベクトルの時間変化が式(19) の線形なシステムモデルで表される場合でのみ適用できる。 しかしながら, 材料工学分野のシミュレーションモデルの多 くは非線形である。非線形なシステムモデルにカルマンフィ ルタと同様のアルゴリズムを適用するためには, 拡張カルマ ンフィルタ, Unscentedカルマンフィルタなどを使用する必 要がある9 。本節では, 非線形なシステムモデルに比較的容 易に適用可能であり, 精度のよいデータ同化が可能なアンサ ンブルカルマンフィルタ 5),23) -25) を紹介する。

アンサンブルカルマンフィルタでは, システムモデルが次 
式で表される場合に適用可能である。

$$
\boldsymbol{x}_{t \mid t-1}=f\left(\boldsymbol{x}_{t-1|| t-1}, \boldsymbol{v}_{t}\right)
$$

ここで, $f$ は非線形なシミュレーションモデルを表す。 2.3 節 で説明したカルマンフィルタでは, 各PDFの平均ベクトル と分散共分散行列の変化をすべて行列計算により追跡できる ことを示した。しかしながら，アンサンブルカルマンフィル 夕ではシミュレーションモデル $f$ が非線形であるため, それ ができない。そこで，図2のようにPDFをモンテカルロ近似 により表現する。すなわち，ある時刻 $t$ での状態べクトル $\boldsymbol{x}_{t}$ に対して，N個のサンプル集合 $\boldsymbol{X}=\left\{\boldsymbol{x}_{\boldsymbol{t}}^{i}\right\}(i=1,2,3, \ldots, N)$ を用 意し，その疎密によってPDFを表現する。モンテカルロ近 似（またはアンサンブル近似）を数式で表現すれば, 次式の ように表される。

$$
p\left(\boldsymbol{x}_{t}\right) \cong \frac{1}{N} \sum_{i=1}^{N} \delta\left(\boldsymbol{x}_{t}-\boldsymbol{x}_{t}^{i}\right)
$$

ここで, $\delta$ はデルタ関数である。アンサンブルカルマンフィ ルタでは, サンプル集合 $\boldsymbol{X}$ をアンサンブルと呼び, $\boldsymbol{x}_{t}^{i}$ のそれ ぞれをアンサンブルメンバーと呼ぶ。そして，PDFを近似す るアンサンブルメンバーの変化を計算することで, PDFの平 均べクトルや分散共分散行列の変化を追跡する。これは例 えば, アンサンブルカルマンフィルタを適用したフェーズ フィールドシミュレーションにおいては, 初期条件やパラ メータを種々に変更してシミュレーションを多数並列に実行 し，それらの結果のヒストグラムとして，PDFの変化を表現 することに等しい。

モンテカルロ近似により，時刻 $t-1$ の状態から時刻 $t$ の状 態の予測は，次式のシステムモデルで計算される。

$$
\boldsymbol{x}_{t \mid t-1}^{i}=f\left(\boldsymbol{x}_{t-1 \mid t-1}^{i}, \boldsymbol{v}_{t}^{i}\right)
$$

ここで， $\boldsymbol{x}_{t \mid t-1}^{i}$ は，時刻 $t-1$ までの観測データを反映したうえ で予測した，時刻 $t$ でのPDFを近似する $i$ 番目アンサンブル メンバーを示す。

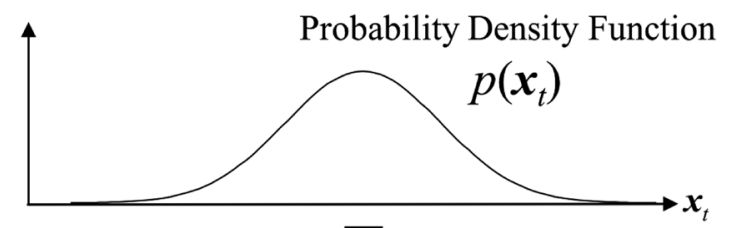

Monte Carlo approximation

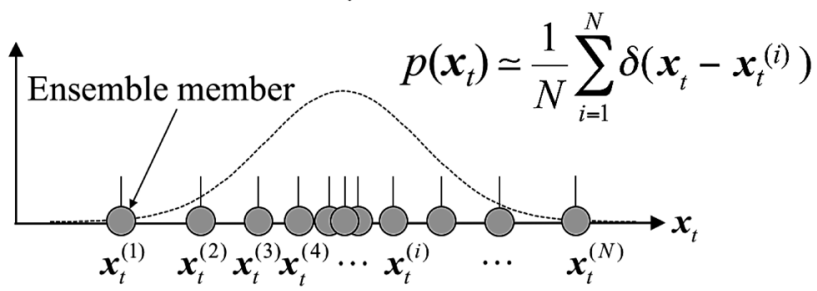

図2 確率密度関数のモンテカルロ近似
カルマンフィルタと同様に, アンサンブルカルマンフィル 夕でもPDFの平均ベクトルと分散共分散行列の変化を計算 する。まず, 平均ベクトルはアンサンブル平均と呼ばれる方 法で計算する。たとえば, 事前分布の平均ベクトルは, 次式 で計算される。

$$
\overline{\boldsymbol{x}}_{t \mid t-1}=\frac{1}{N} \sum_{i=1}^{N} \boldsymbol{x}_{t \mid t-1}^{i}
$$

また, 事前分布の共分散行列, すなわち予測誤差共分散行列 は，次式のように計算される。

$$
\boldsymbol{P}_{t \mid t-1}=\frac{1}{N-1} \sum_{i=1}^{N}\left(\boldsymbol{x}_{t \mid t-1}^{i}-\overline{\boldsymbol{x}}_{t \mid t-1}\right)\left(\boldsymbol{x}_{t \mid t-1}^{i}-\overline{\boldsymbol{x}}_{t \mid t-1}\right)^{\mathrm{T}}
$$

時刻 $t$ での実験データを反映した事後分布は, 事前分布を 近似する各アンサンブルメンバーに対して, カルマンフィル 夕における式(23) と同様の計算を行うことで得られる。こ れをアンサンブルアップデートと呼び, 次式で表される。

$$
\boldsymbol{x}_{t \mid t}^{i}=\boldsymbol{x}_{t \mid t-1}^{i}+\boldsymbol{K}_{t}\left(\boldsymbol{y}_{t}+\breve{w}_{t}^{i}-\boldsymbol{H} \boldsymbol{x}_{t \mid t-1}^{i}\right)
$$

ここで, $\boldsymbol{y}_{t}+\breve{\boldsymbol{w}}_{t}^{i}$ は擾乱付き観測と呼ばれる。さらに, アンサ ンブルカルマンフィルタにおけるカルマンゲインは, 式(24) で示したカルマンフィルタでのカルマンゲインと同様に, 次 式で与えられる。

$$
\boldsymbol{K}_{t}=\boldsymbol{P}_{t \mid t-1} \boldsymbol{H}^{T} \boldsymbol{S}_{t}^{-1}
$$

ここで, $\boldsymbol{S}_{t}^{-1}$ は式(25) と同じであるが, 観測誤差共分散行列 $\boldsymbol{R}_{t}$ は式(31) と同様に, アンサンブルを用いて次式で計算さ れる。

$$
\boldsymbol{R}_{t}=\frac{1}{N-1} \sum_{i=1}^{N}\left(\boldsymbol{w}_{t \mid t-1}^{i}-\overline{\boldsymbol{w}}_{t \mid t-1}\right)\left(\boldsymbol{w}_{t \mid t-1}^{i}-\overline{\boldsymbol{w}}_{t \mid t-1}\right)^{\mathrm{T}}
$$

そして, アンサンブルカルマンフィルタでも事後分布の分散 共分散行列, すなわち解析誤差共分散行列は式(26)で計算 される。

以上のように，アンサンブルカルマンフィルタでもカルマ ンフィルタと同様に, シミュレーションモデルで予測する状 態変数を各成分とする状態べクトル $\boldsymbol{x}_{t}$ を確率変数として, 実 験データがない時間においては $\boldsymbol{x}_{t}$ のPDFの平均べクトルと 分散共分散行列の時間変化を予測する。また, 実験データが 得られた時刻では, ベイズの定理と実験データの平均ベクト ルと分散共分散行列に基づき, 事後分布の平均べクトルと分 散共分散行列の変化を計算する。このとき, 2.2 節で説明し たように，事後分布は実験デー夕を表す尤度に近づき，かつ シミュレーション結果の不確かさも減少する。

次節では, マルチフェーズフィールド法による静的再結晶 の粒成長シミュレーションにアンサンブルカルマンフィルタ を適用した事例を示す。 


\section{3. マルチフェーズフィールド法による静的再結晶 シミュレーションヘのアンサンブルカルマン フィルタの適用}

\section{1 粒界特性の結晶方位差依存性の推定}

アルミニウム合金板の再結晶集合組織は，主にcube方位 に配向する ${ }^{26)}$ 。その理由の 1 つして， 57 粒界の粒界エネ ルギーと粒界モビリティーの異方性がある。 27 粒界は, 通 常の粒界よりも粒界モビリティーが大きい。したがって, cube方位を有する再結晶粒は，圧延集合組織の主成分である $\mathrm{S}$ 方位を有する母相との間に 27 粒界を形成するため， S 方位 の母相を急速に浸蝕して成長すると考えられている ${ }^{26)}$ 。ま た， 57 粒界は，通常の粒界よりも粒界エネルギーが小さい。 そのため, S 方位の母相に隣接する cube 方位の再結晶粒は, 粒界の曲率による駆動力が小さくなり，より成長しやすいと されている ${ }^{26)}$ 。それ攼え，アルミニウム合金板の再結晶集 合組織の予測には， 57 粒界に扔ける粒界モビリティーおよ び粒界エネルギーの異方性が重要となる。実験により粒界の 移動速度を測定することは可能であるが，駆動力を正確に測 定することは困難である。よって，粒界モビリティーの異方 性を実験によって測定することは難しい。一方で，最近では $3 \mathrm{DXRD}^{27)}$ やX線トモグラフィー ${ }^{28)}$ で，多結晶体中の結晶粒 の成長をその場観察する実験技術も進展しており,こうした 最先端の実験技術で得られる実験デー夕をデー夕同化により シミュレーションに統合することが期待される。

本章では, アンサンブルカルマンフィルタをマルチフェー ズフィールド法による再結晶粒成長の数值シミュレーション に適用し，再結晶粒と変形母相との間の粒界エネルギーと粒 界モビリティーを表すパラメー夕および変形母相の蓄積エネ ルギーを逆推定した数值実験（双子実験）の事例を紹介する。

\section{2 双子実験}

双子実験では，実際の実験デー夕を用いたデー夕同化を行 うのではなく, シミュレーションで生成した計算デー夕を仮 想的な擬似実験デー夕とみなして, デー夕同化を行い, デー 夕同化アルゴリズムの適用可能性を検証する ${ }^{3)}$, 4)。はじめ に，粒界エネルギーおよび粒界モビリティーの異方性を表す パラメー夕の真值を仮定し，それを用いた再結晶粒成長のシ ミュレーションを行う。その結果として得られる, 再結晶粒 分布の時間変化を擬似実験デー夕としてデー夕同化を行い, 仮定したパラメータの真值を推定できるかを検証する。

\section{3 静的再結晶による粒成長のマルチフェーズフィール ドモデル}

静的再結晶による再結晶粒の成長を表すマルチフェーズ フィールドモデルを説明する。 $N_{\mathrm{def}}$ 個の変形母相粒と $N_{\mathrm{rex}}$ 個 の再結晶粒の合計 $N=N_{\mathrm{def}}+N_{\mathrm{rex}}$ 個の結晶粒からなる多結晶組 織を想定する。ある $i(i=1,2, \ldots, N)$ 番目の結晶粒（以後, 結晶粒 $i$ と呼ぶ）の座標 $\boldsymbol{r}$, 時刻 $t$ に招ける存在確率を表す秩 序変数 $\eta_{i}(\boldsymbol{r}, t)$ を定義する。 $\eta_{i}$ は, 結晶粒 $i$ の内部では $\eta_{i}=1$, 結晶粒 $i$ の外側では $\eta_{i}=0$, 粒界領域では $0<\eta_{i}<1$ の範囲で滑ら かに変化すると定義する。秩序変数 $\eta_{i}$ の時間変化を計算する ことで，各結晶粒の成長，収縮ならびに粒界移動を解析する ことができる。
Fan ${ }^{29)}$ が提案したマルチフェーズフィールド法では, 次 式に示す系の全自由エネルギーに基づき， $\eta_{i}$ の時間発展方程 式を導出する。

$$
G=\int_{V}\left[\begin{array}{c}
\left\{\sum_{i=1}^{N}\left(-\frac{\alpha}{2} \eta_{i}^{2}+\frac{\beta}{4} \eta_{i}^{4}\right)+\sum_{i=1}^{N} \sum_{j \neq i}^{N} \gamma_{i j} \eta_{i}^{2} \eta_{j}^{2}\right\} \\
+\frac{\kappa}{2} \sum_{i=1}^{N}\left(\nabla \eta_{i}\right)^{2}+\sum_{i=1}^{N} h\left(\eta_{i}\right) E_{i}
\end{array}\right] d V
$$

ここで, 式(35) 右辺の被積分関数の第 1 項は, 倸数 $\alpha, \beta, \gamma_{i j}$ が $\alpha=\beta>0$ かつ $\gamma_{i j}>\beta / 2$ を満たすとき $\left(\eta_{1}, \eta_{2}, \ldots, \eta_{N}\right)=( \pm 1,0, \ldots, 0)$, $(0, \pm 1, \ldots, 0), \ldots,(0,0, \ldots, \pm 1)$ で最小值をとる関数であ り, 各結晶粒が独立して存在するために必要な項である。第 2 項は，粒界領域での秩序変数の滑らかな変化を保証するた めに導入される勾配エネルギーである。本研究では， $\alpha=1.0$, $\beta=1.0, \kappa=1.0$ とするため, 時間㧍よびエネルギーは無次元量 となる。第 3 項は, 蓄積エネルギー密度であり， $E_{i}$ は結晶粒 门の蓄積エネルギーである。本研究では, 再結晶粒の蓄積エ ネルギーは 0 と仮定し， $E_{i}=0 \quad\left(i=N_{d e f}+1, \ldots, N\right)$ とする。 $h\left(\eta_{i}\right)$ は任意の座標に扮ける結晶粒 $i$ の局所的な体積分率を表す関 数であり, 次式で定義される ${ }^{30)}$ 。

$$
h\left(\eta_{i}\right)=\frac{\eta_{i}^{2}}{\sum_{j=1}^{N} \eta_{j}^{2}}
$$

式(35) の系の全自由エネルギーが時間とともに減少する ように, 再結晶粒の成長は進行すると仮定すると, 秩序変数 $\eta_{i}$ の時間変化は, 次式に示す時間発展方程式を解くことで解 析できる ${ }^{30)}$

$$
\frac{\partial \eta_{i}}{\partial t}=-L\left\{\begin{array}{c}
\eta_{i}^{3}-\eta_{i}+2 \eta_{i} \sum_{j \neq i}^{n} \gamma_{i j} \eta_{j}^{2}-\kappa \nabla^{2} \eta_{i} \\
+\frac{2\left(E_{i} \eta_{i} \sum_{j=1}^{n} \eta_{j}^{2}-\eta_{i} \sum_{j=1}^{n} E_{j} \eta_{j}^{2}\right)}{\left(\sum_{j=1}^{n} \eta_{j}^{2}\right)^{2}}
\end{array}\right\} \quad(i=1,2, \ldots, n)
$$

ここで, $n$ は任意の座標 $\boldsymbol{r}$ に执いて 0 より大きい秩序変数の個 数を表す。また, $\gamma_{i j}$ は結晶粒 $i$ と結晶粒 $j$ の粒界エネルギーを

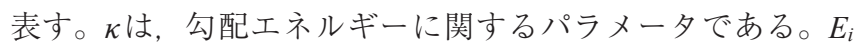
は, 結晶粒 $i$ 内部の均一な蓄積エネルギーの大きさを表す。 $L$ は, 座標 $\boldsymbol{r}$ での秩序変数の易動度であり, 次式で表され る $^{31)}$ 。

$$
L=\frac{\sum_{i \neq j}^{n} \eta_{i}^{2} \eta_{j}^{2} M_{i j}}{\sum_{i \neq j}^{n} \eta_{i}^{2} \eta_{j}^{2}}
$$

ここで, $M_{i j}$ は結晶粒 $i$ と結晶粒 $j$ がなす粒界のモビリティーを 表す。本稿で示す事例では，変形母相粒間の粒界移動は生じ ないと仮定し， $1 \leq i \leq N_{\text {def }}$ かつ $1 \leq j \leq N_{\text {def }}$ のときには， $M_{i j}=0$ と 

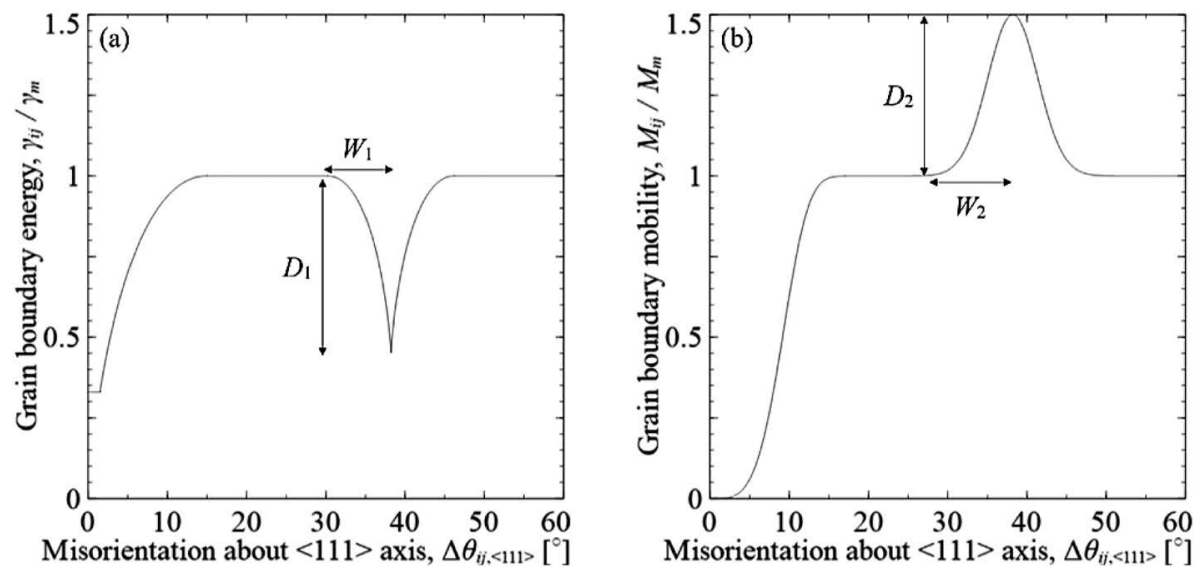

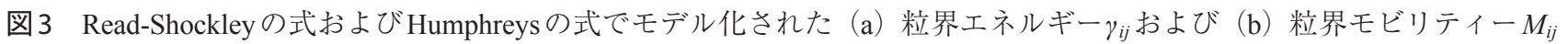
の結晶方位差依存性

した。

本事例では，粒界エネルギー $\gamma_{i j}$ と粒界モビリティー $M_{i j}$ は， 結晶粒 $i$ と結晶粒 $j$ がなす粒界での〈111〉軸まわりの結晶方 位差 $\Delta \theta_{i j}\langle 111\rangle$ と $\Sigma 7$ 粒界での結晶方位差とのずれ量に応じて 変化する異方性があると仮定する。粒界エネルギーの結晶方 位差依存性は, Read-Shockleyの式 ${ }^{32)}$ を用いて次式のように モデル化する。

$\gamma_{i j}=\gamma_{m} \times\left\{\begin{array}{r}\frac{\Delta \theta_{i j,\langle 111\rangle}}{\Delta \theta_{m}}\left\{1-\log \left(\frac{\Delta \theta_{i j,\langle 111\rangle}}{\Delta \theta_{m}}\right)\right\} \\ 1-D_{1}\left\{1-\frac{\left|\Delta \theta_{i j,\langle 111\rangle}-\Delta \theta_{\Sigma 7}\right|}{W_{1}}\left(1-\log \left(\frac{\left|\Delta \theta_{i j,\langle 111\rangle}-\Delta \theta_{\Sigma 7}\right|}{W_{1}}\right)\right)\right\} \\ \left(\left|\Delta \theta_{i j,\langle 111\rangle}-\Delta \theta_{\Sigma 7}\right|<W_{1}\right) \\ \left(\Delta \theta_{i j,\langle 111\rangle}>\Delta \theta_{m} \text { and }\left|\Delta \theta_{i j,\langle 111\rangle}-\Delta \theta_{\Sigma 7}\right|>W_{1}\right)\end{array}\right.$

ここで, $\Delta \theta_{\Sigma 7}=38.21^{\circ}$ は $\Sigma 7$ 粒界での〈111〉軸まわりの結晶 方位差である。結晶方位差の計算方法は, 文献21）を参照 されたい。また, 粒界モビリティーの結晶方位差依存性は, Humphreys の式 ${ }^{33)}$ を用いて, 次式でモデル化する。

$$
M_{i j}=M_{m} \times\left\{\begin{array}{c}
1-\exp \left\{-5\left(\frac{\Delta \theta_{i j,\langle 111\rangle}}{\Delta \theta_{m}}\right)^{4}\right\} \\
\left(\Delta \theta_{i j,\langle 11\rangle} \leq \Delta \theta_{m}\right) \\
1-D_{2} \exp \left(-5\left(\frac{\left|\Delta \theta_{i j,\langle 111\rangle}-\Delta \theta_{\Sigma 7}\right|}{W_{2}}\right)^{2}\right) \\
\left(\left|\Delta \theta_{i j,\langle 111\rangle}-\Delta \theta_{\Sigma 7}\right|<W_{2}\right) \\
\left(\Delta \theta_{i j,\langle 111\rangle}>\Delta \theta_{m} \text { and }\left|\Delta \theta_{i j,\langle 111\rangle}-\Delta \theta_{\Sigma 7}\right|>W_{2}\right)
\end{array}\right.
$$

式(39) と式(40) において， $\gamma_{m}$ と $M_{m}$ は，それぞれ結晶方 位差が $15^{\circ}$ 以上の高角粒界の粒界エネルギーと粒界モビリ ティーを表し， $\gamma_{m}=1.5$ と $M_{m}=0.5$ とする。また， $D_{1}$ と $W_{1}$ は, それぞれ粒界エネルギーのカスプの深さと幅を決定するパ ラメータである。 $D_{2}$ と $W_{2}$ は, それぞれ粒界モビリティー のカスプの高さと幅を決定するパラメータである。図3に,
$D_{1}=0.5, W_{1}=8^{\circ}, D_{2}=0.5, W_{2}=10^{\circ}$ とした場合の粒界エネルギーと 粒界モビリティーの結晶方位差依存性を図示する。

本事例では, 変形母相の蓄積エネルギーは回復により時間 とともに減少することを考慮し $E_{i}\left(i=1,2, \ldots, N_{\mathrm{def}}\right)$ の時間 変化を次式で表現する ${ }^{34)}$ 。

$$
E_{i}=\frac{E_{i}^{0}}{E_{i}^{0} c t+1}
$$

ここで, $E_{i}^{0}$ は結晶粒 $i$ の初期の蓄積エネルギー, $c$ は回復に よる蓄積エネルギーの減少速度を決定するパラメータであ る。

本事例では，再結晶粒の成長の 4 次元的な実験デー夕（各 結晶粒の 3 次元形態の時間変化) が得られた場合を想定して, アンサンブルカルマンフィルタに基づくデータ同化により, 粒界エネルギーと粒界モビリティーの異方性を表すパラメー 夕である $D_{1}, W_{1}, D_{2}, W_{2}$ と各結晶粒内の蓄積エネルギーであ る $E_{i}\left(i=1,2, \ldots, N_{\mathrm{def}}\right)$ を逆推定できるかを検証する。

\section{4 双子実験の条件}

双子実験を実施するために，粒界エネルギーと粒界モビリ ティーの異方性に関するパラメータおよび蓄積エネルギーの 真值を仮定して, シミュレーションを行い, 擬似実験デー 夕を作成する。擬似観測デー夕を作成するために実施する シミュレーションの初期組織は, 16個の変形母相粒と 16 個 の再結晶粒からなる多結晶組織とする。計算領域は, 96×96 $\times 96$ の規則差分格子で分割し, 全方向に周期境界条件を適用 する。時間増分は $\Delta t=0.05$, 差分格子間隔は 1.0 とした。再結 晶粒の位置はランダムに決定する。変形母相粒と再結晶粒 の初期結晶方位は, 多結晶組織内に $\Sigma 7$ 粒界が存在するよう に設定する。Bungeのオイラー角の定義に従い, Cube方位 は $\left(\phi_{1}, \phi, \phi_{2}\right)=\left(90^{\circ}, 90^{\circ}, 90^{\circ}\right), \mathrm{S}$ 方位は $\left(\phi_{1}, \phi, \phi_{2}\right)=\left(59^{\circ}, 37^{\circ}\right.$, 63）で表されるが，その粒界は正確な 57 粒界とならない。 そこで, $\left(\phi_{1}, \phi, \phi_{2}\right)=\left(95^{\circ}, 92^{\circ}, 94^{\circ}\right)$ と $\left(\phi_{1}, \phi, \phi_{2}\right)=\left(58^{\circ}, 35^{\circ}\right.$, $\left.60^{\circ}\right)$ の結晶方位差が正確な $\Sigma 7$ 方位での結晶方位差となるこ とを利用して, 再結晶粒には $\left|\phi_{1}-95^{\circ}\right|<4^{\circ},\left|\phi^{\circ}-92^{\circ}\right|<4^{\circ},\left|\phi_{2}-94^{\circ}\right|$ $<4^{\circ}$ を満たすオイラー角をランダムに割り当てる。変形母相 粒には $\left|\phi_{1}-58^{\circ}\right|<4^{\circ},\left|\phi^{-} 35^{\circ}\right|<4^{\circ},\left|\phi_{2}-60^{\circ}\right|<4^{\circ}$ を満たすオイラー 
$6 \quad|||||||||||||||||||||||||||||||||||||||||||||||||||||||||||||||||||||||||||||||||||||||||||||||||||||||||||||||||||||||||||||||||||||||||||||||||||||||||||||||||||||||||||||||||||||||||||||||||||||||||||||||||||||||||||||||||||||||||||||||||||||||||||||||||||||||||||||||||||||||||||||||| \mid$
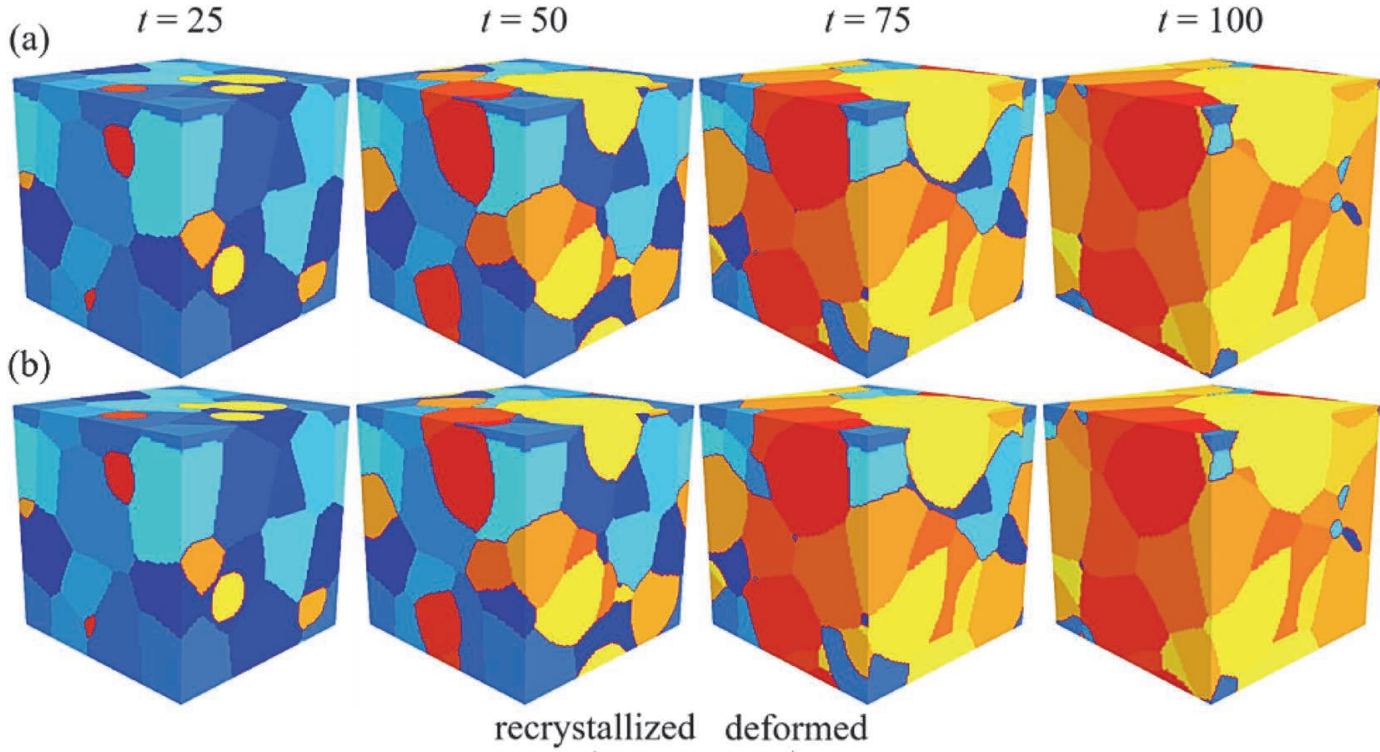

図4 再結晶粒の成長過程の（a）擬似実験データと（b）双子実験においてアンサンブルカルマンフィルタにより推定さ れた再結晶粒の成長
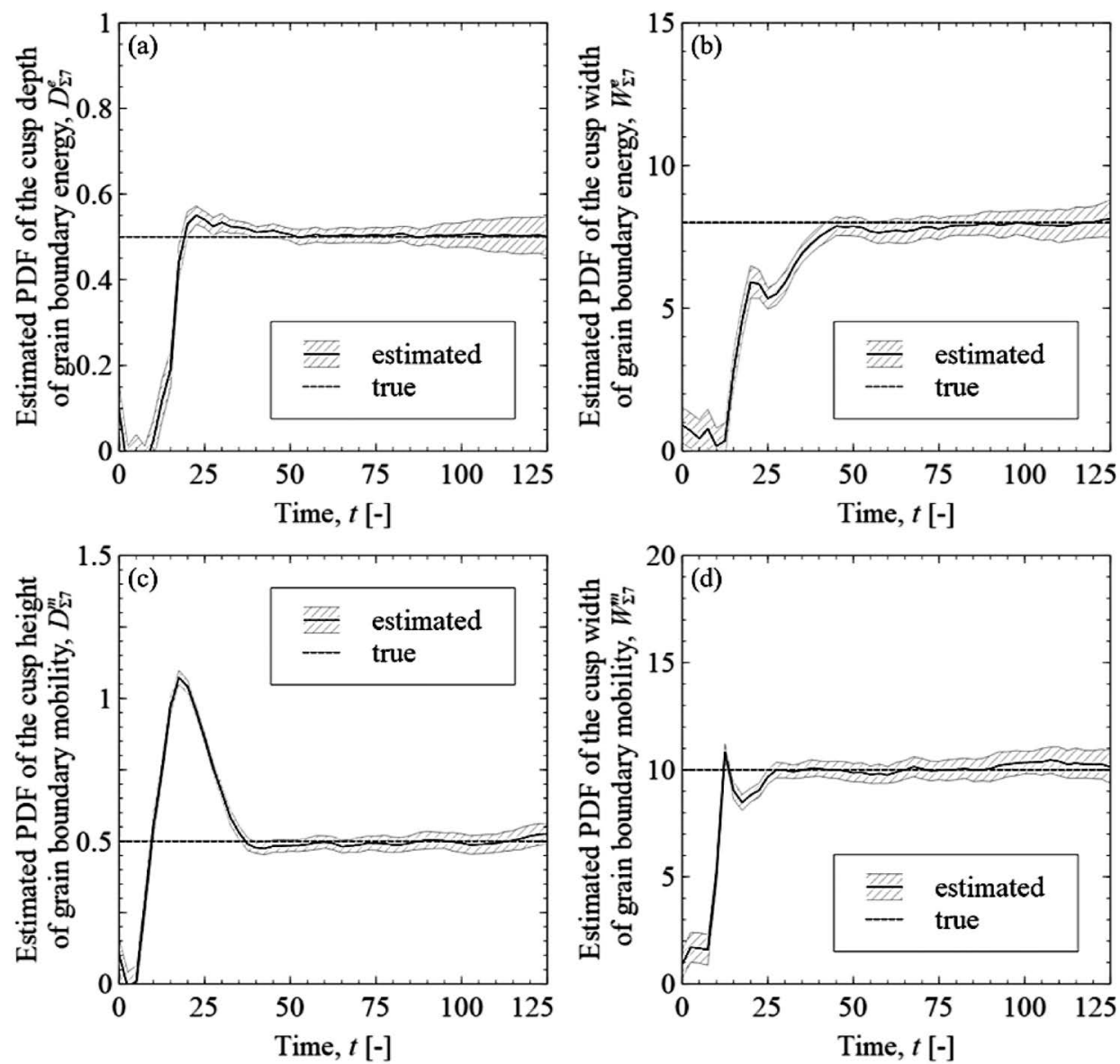

図 5 双子実験においてアンサンブルカルマンフィルタにより推定された 7 粒界での粒界エネルギーのカスプの（a）深 さを表すパラメータ $\left.D_{1}, （ \mathrm{~b}\right)$ 幅を表すパラメータ $W_{1}$, 粒界モビリティーのカスプの (c) 高さを表すパラメータ $D_{2}$, （d）幅を表す $W_{2}$ の平均值とそれらの標準偏差（不確かさ）の時間変化 

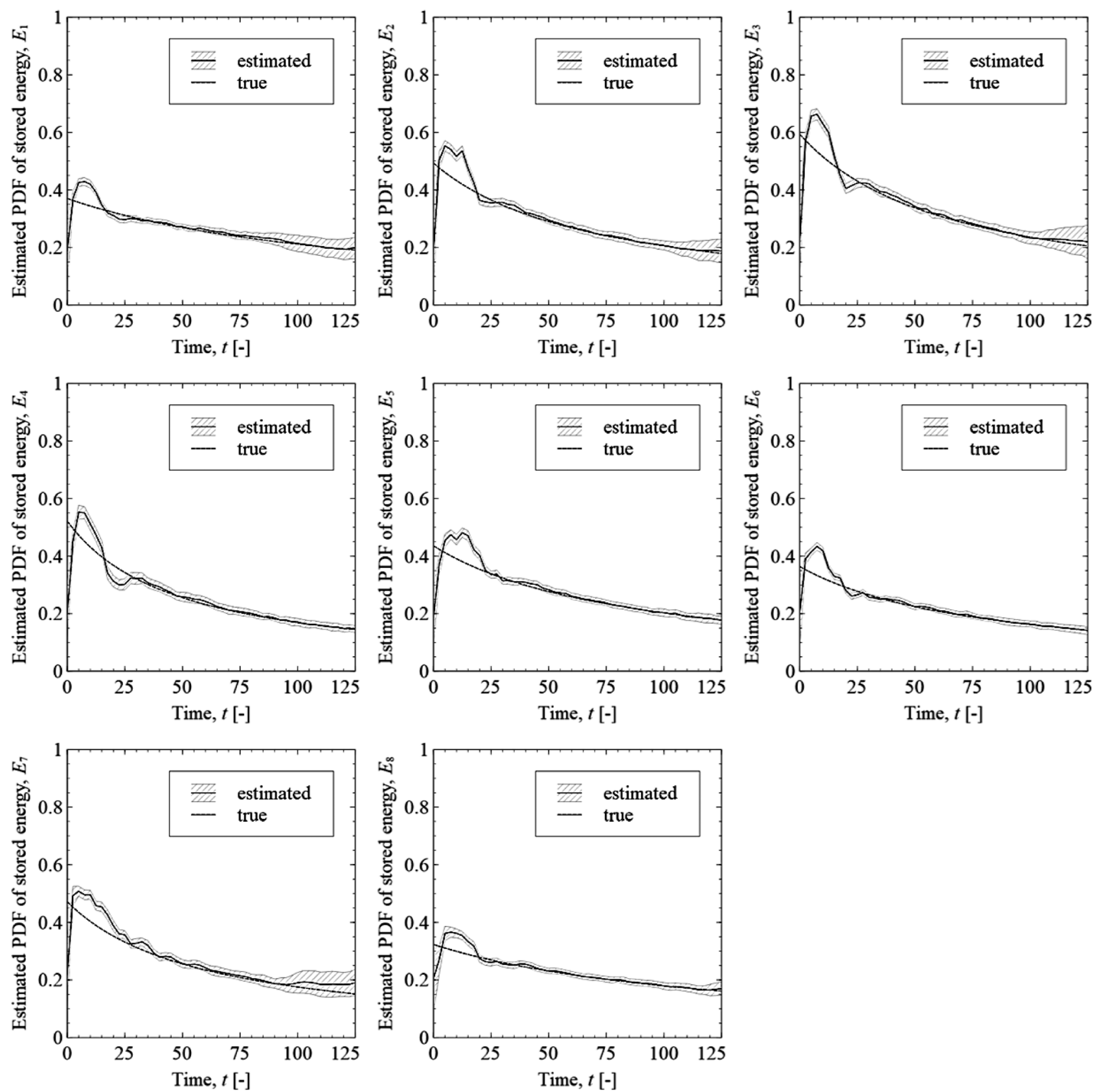

図6 双子実験においてアンサンブルカルマンフィルタにより推定された結晶粒番号 1 ～8の変形母相粒の蓄積エネルギー の時間変化

角をランダムに割り当てる。また，蓄積エネルギーの初期 值 $E_{i}^{0}$ は, 0.3 以上 0.6 以下で結晶粒ごとにそれぞれ異なる值 をランダムに設定する。また，各結晶粒での回復による蓄積 エネルギーの減少を特徴づけるパラメータである $c_{i}$ は 0.02 か ら 0.04 の範囲でランダムに設定する。粒界エネルギーと粒界 モビリティーの異方性に関するパラメータ $D_{1}, D_{2}, W_{1}, W_{2}$ の 真值は, 図3に示したものと同じとし, それぞれ $0.5,0.5,8^{\circ}$, 10 とする。

上記の条件で実施するシミュレーションの結果を擬似実験 データとし，それを成分とする観測ベクトルを定義する。本 事例では, 観測べクトル $\boldsymbol{y}_{t}$ は, 次式で与えられるものとする。

$$
\boldsymbol{y}_{t}=\left(\begin{array}{lllllllll}
\eta_{1,1}^{t} & \eta_{1,2}^{t} & \cdots & \eta_{1, N_{\text {gid }}}^{t} & \cdots & \eta_{N, 1}^{t} & \eta_{N, 2}^{t} & \cdots & \left.\eta_{N, N_{\text {grid }}}^{t}\right)^{T}
\end{array}\right.
$$
ここで, $\eta_{i, j}^{t}\left(i=1,2, \ldots, N, j=1,2, \ldots, N_{\text {grid }}\right)$ は，全計算格子点 数を $N_{\text {grid }}$ としたときの時刻 $t$ における $j$ 番目の計算格子点の $i$ 番目の秩序変数である。これは, 実際の実験デー夕における, 各観測点での結晶粒の有無もしくは結晶方位と考えることが できる。

一方，本事例における状態べクトル $\boldsymbol{x}_{t}$ は，次式で与えられ る。

$$
\begin{aligned}
\boldsymbol{x}_{t}=\left(\begin{array}{llllllllll}
\eta_{1,1}^{t} & \eta_{1,2}^{t} & \cdots & \eta_{1, N_{\text {grid }}}^{t} & \cdots & \eta_{N, 1}^{t} & \eta_{N, 2}^{t} & & \\
\cdots & \eta_{N, N_{\text {grid }}}^{t} & D_{1}^{t} & D_{2}^{t} & W_{1}^{t} & W_{2}^{t} & E_{1}^{t} & \cdots & E_{N_{d e f}}^{t}
\end{array}\right)^{T}
\end{aligned}
$$

ここで, $D_{1}^{t}, D_{2}^{t}, W_{1}^{t}, W_{2}^{t}, E_{\mathrm{i}}^{t}$ は, それぞれ時刻 $t$ において, ア 
ンサンブルカルマンフィルタにより推定される粒界エネル ギーと粒界モビリティーの異方性に関する $D_{1}, D_{2}, W_{1}, W_{2}$ と 結晶粒での蓄積エネルギー $E_{i}$ である。

アンサンブルカルマンフィルタによるデータ同化で使用す るアンサンブル数, すなわち並列に実行するシミュレーション の数は $N_{p}=100$ とし, 観測データを取り込む時間間隔は $\Delta t_{\mathrm{samp}}=$ 2.5 とする。また, $D_{1}, D_{2}, W_{1}, W_{2}, E_{i}$ の初期推定值は, $N_{p}$ 個の シミュレーション, すなわち各アンサンブルメンバーで異な る。各アンサンブルメンバーでの $D_{1}, D_{2}, W_{1}, W_{2}$ の初期推定 值は，それぞれの平均值が $0.1,0,11.0,1.0$, それぞれの初期 標準偏差が 0.06, 0.06, 0.6, 0.6のガウス分布に従うように設定 する。また, $E_{i}$ の初期分布の平均值は 0.2 , 標準偏差は 0.12 のガウス分布に従うように設定する。

\section{5 アンサンブルカルマンフィルタによる粒界特性異方 性と蓄積エネルギーの逆推定結果}

図4(a) に，粒界エネルギーと粒界モビリティーの異方性 に関するパラメータと蓄積エネルギーの真值を用いて実施し たシミュレーション結果，すなわち擬似実験デー夕を示す。 図中において，寒色で示す結晶粒が変形母相粒であり，暖色 で示す結晶粒は再結晶粒を表す。再結晶粒は，変形母相粒の 蓄積エネルギーを駆動力として, 成長することがわかる。図 4(b)に, アンサンブルカルマンフィルタにより擬似実験デー 夕を用いた双子実験の結果を示す。双子実験においては，粒 界エネルギーと粒界モビリティーの異方性に関するパラメー 夕や蓄積エネルギーは, 真值と大きく異なる初期值を用い た。それにも関わらず，アンサンブルカルマンフィルタによ り擬似実験データの再結晶の粒成長を高精度に再現する結果 が得られていることがわかる。

図 5 に, 双子実験における $D_{1}^{t}, D_{2}^{t}, W_{1}^{t}, W_{2}^{t}$ の時間変化を示 す。図 5 の横軸は, 図4(b) に示した再結晶粒成長の時間と 同じであることに注意されたい。また，図5の太い実線は, 事後分布の平均ベクトルに相当する各パラメータの推定值 の平均值を表す。また，太い実線の周囲のハッチングの幅 は, 事後分布の標準偏差に相当し, 各パラメータの推定值の 不確かさを表す。本事例では, 各パラメータの真值がこの標 準偏差内に含まれていれば, アンサンブルカルマンフィルタ によって各パラメータの真值を推定できていると判断する。 各パラメータの推定值は，擬似実験データを反映するたびに 初期值から真值に近づき, $D_{1}^{t}, D_{2}^{t}, W_{1}^{t}$ では $t=50$ 以降, $W_{2}^{t}$ では $t=30$ 以降で真值を精度よく推定できることがわかる。さら に, $t=75$ 以降には, 事後分布の標準偏差が大きくなることが わかる。これは, 時間とともに再結晶粒が成長し, 変形母相 と再結晶粒の粒界が減少したことに起因する。

図6に，双子実験においてアンサンブルカルマンフィルタ により推定された $E_{i}$ の推定結果を示す。ここで，16個の変 形母相の結晶粒のうち, 代表的な 8 個の結果を示す。図 5 と 同様に，太い実線は，事後分布の平均ベクトルに相当する $E_{i}$ の推定值の平均值を表す。太い実線の周囲のハッチングの 幅は, 事後分布の標準偏差に相当し， $E_{i}$ の推定值の不確かさ を表す。双子実験における蓄積エネルギーの初期值は, 真值 よりも小さいにもかかわらず，時間の経過とともに擬似実験 データを反映することで, 変形母相粒の蓄積エネルギーとそ
の時間変化を推定できることがわかる。結晶粒番号 3 と 7 に おいては, 後半に蓄積エネルギーの推定值が真值から乘離す る。これは, 結晶粒番号 3 と 7 の変形母相粒が, 再結晶粒に 浸蝕されて消滅したため, 実験デー夕を反映したとしても, 必要な情報が欠落しているためである。

以上に示した双子実験の結果より, 逐次デー夕同化を適用 したマルチフェーズフィールドシミュレーションの利点は次 のように総括することができる。すなわち，アンサンブルカ ルマンフィルタのような逐次データ同化を用いることで, 再 結晶粒の成長に関する時系列の実験データがあれば, 最初は パラメータや変形母相粒の状態が不明であっても, 実験デー タをマルチフェーズフィールド法による再結晶シミュレー ションの結果に時々刻々と反映することで，未知パラメータ や未知の状態を逆推定できる。さらには, 最終的には実験 データを高精度に再現するシミュレーション結果を得ること ができる。これはデー夕同化の適用により, 従来のフェーズ フィールド法やマルチフェーズフィールド法のみを用いた材 料組織形成シミュレーションを飛躍的に高度化することを意 味する。

\section{4. おわりに}

本解説では, データ同化との融合によるマルチフェーズ フィールドシミュレーションの進展の一例を紹介した。特 に，逐次データ同化アルゴリズムであるアンサンブルカル マンフィルタを, マルチフェーズフィールド法に基づく再結 晶粒成長シミュレーションに適用した事例を紹介した。その 結果, 数值実験での例示ではあるが, 再結晶粒成長の時系列 データがあれば, シミュレーションに必要なパラメータの逆 推定が可能であることを示した。また, パラメータの逆推定 と同時に, 再結晶粒の成長挙動や変形母相の状態推定も可能 であり，最終的には実験デー夕を高精度に再現することがで きることを示した。

本講座で説明したように，デー夕同化はベイズの定理をは じめとする確率論や統計学の知識を必要とするため, 読者が 日常的に行うシミュレーションに適用するには, 困難と時間 を要することも予想される。本稿が, そのような困難を少し でも減らすことにつながれば，著者にとっては望外の喜びで ある。また，本稿で紹介した逐次デー夕同化アルゴリズムで あるアンサンブルカルマンフィルタでは，初期条件が異なる 複数のシミュレーションを同時に実行する必要がある。シ ミュレーションの種類や推定したいパラメータの個数によっ ては, 数 100 のアンサンブルを必要とし, 非常に大きな計算 リソースを必要とすることがある。その解決策として，ア ンサンブルカルマンフィルタをさらに発展させた局所アン サンブル変換カルマンフィルター（Local Ensemble Transform Kalman Filter; LETKF）などの新しい逐次データ同化アルゴ リズムが提案されている。LETKFは, フェーズフィールド 法による $\mathrm{Al}-\mathrm{Cu}$ 合金のデンドライト凝固形成のシミュレー ションに適用 ${ }^{35)}$ されており, 今後のさらなる進展が期待さ れる。

\section{謝 辞}

本講座において紹介した研究成果は, 総合科学技術・イノ 
ベーション会議SIP（戦略的イノベーション創造プログラム） 「革新的構造材料（管理法人：JST）」および科学研究費補助 金基盤研究（B）（課題番号：17H03425）のもと実施した成 果です。ここに記して謝意を表します。

\section{参 考 文 献}

1）村山光宏：まてりあ, 51 (2012), 462-466.

2) R. Kobayashi: Physica D, 63 (1994), 410-423.

3) 淡路敏之, 蒲地政史, 池田元美, 石川洋一：データ同化 観 測・実験とモデルを融合するイノベーション，京都大学学術出 版会, (2009).

4) 樋口知之, 上野玄太, 中野慎也, 中村和幸, 吉田 亮：デー 夕同化入門一次世代のシミュレーション技術—, 朝倉書店, (2011).

5) G. Evensen: Physica D, 77 (1994), 108-129.

6) R. E. Kalman: J. Basic Eng., 82 (1960), 35-45.

7) 前田悠里, 山中晃德, 佐々木健吾：日本機械学会第 31 回計算 力学講演会講演論文集, No. 18-8（2018），67.

8) 樋口知之: 予測にいかす統計モデリングの基本, 講談社, (2011).

9) 片山 徹：非線形カルマンフィル夕, 朝倉書店, (2011).

10) G. Evensen: Data Assimilation-The Ensemble Kalman Filter, 2nd ed., Springer,(2009).

11) W. Lahoz, B. Khattatov and R. Menard eds.: Data Assimilation, Making Sense of Observation, Springer,(2010).

12) 高木知弘, 山中晃徳：フェーズフィールド法一数值シミュレー ションによる材料組織設計一，養賢堂，(2012）。

13) 小山敏幸, 高木知弘：フェーズフィールド法入門, 計算力学レ クチャーシリーズ, 丸善出版, (2013).

14）小山敏幸：ふえらむ, 9 (2004)，240-245, 301-305, 376-381, 497503.

15）高木知弘，山中晃徳：塑性と加工，54（2013），906-910.
16）山中晃德, 高木知弘：ふえらむ，19（2014）, 765-774.

17）小山敏幸，塚田祐貴：ふえらむ，23（2019），680-686.

18) S. Ito, H. Nagao, A. Yamanaka, Y. Tsukada, T. Koyama, M. Kano and J. Inoue: Phys. Rev. E, 94 (2016), 043307.

19) S. Ito, H. Nagao, T. Kasoya and J. Inoue: Sci. Technol. Adv. Mater., 18 (2017), 857-869

20) K. Sasaki, A. Yamanaka, S. Ito and H. Nagao: Comput. Mater. Sci., 141 (2018), 141-152.

21) A. Yamanaka, Y. Maeda and K. Sasaki: Mater. Des., 165 (2019), 107577.

22）豊田秀樹 : 基礎からのベイズ統計学ハミルトニアンモンテカル 口法による実践的入門，朝倉書店，(2015）。

23) G. Evensen and P. J. van Leeuwen: Mon. Weather Rev., 124 (1996), $85-96$.

24) G. Evensen: Mon. Weather Rev., 125 (1997), 1342-1354.

25) G. Evensen: Ocean Dyn., 53 (2003), 343-367.

26) F. J. Humphreys and M. Hartherly: Recrystallization and Related Annealing Phenomena. 2nd ed., Pergamon Press. Oxford, (2004).

27) E. M. Lauridsen, S. Schmidt, S. F. Nielsen, L. Margulies, H. F. Poulsen and D. Juul Jensen: Scr. Mater., 55 (2006), 41-56.

28) C. M. Hefferan, J. Lind, S. F. Li, U. Lienert, A. D. Rollett and R. M. Suter: Acta Mater., 60 (2012), 4311-4318.

29) D. Fan and L. Q. Chen: Acta Mater., 45 (1997), 611-622.

30) N. Moelans, A. Godfrey, Y. Zhang and D. J. Jensen: Phys. Rev. B, 88 (2013), 054103

31) N. Moelans, B. Blanpain and P. Wollants: Phys. Rev. B, 78 (2008), 024113.

32) W. T. Read and W. Shockley: Phys. Rev., 78 (1950), 275-289.

33) F. J. Humphreys: Acta Mater., 45 (1997), 4231-4240.

34) American Society for Metals: Recrystallization, Grain Growth, and Textures, American Society for Metals, (1966).

35) 高橋和希, 山中晃徳: 軽金属学会第 136 回春期大会講演概要, (2019) , 307-308. 